\title{
Technical Efficiency and Profitability among Maize Based Farmer in Kajola Local Government of Oyo State
}

\author{
Matthew Olufemi ADIO* ${ }^{1}$ and Adebola Toyin OLAOYE ${ }^{2}$ \\ *IDepartment of Agricultural Economics and Extension, Faculty of Agriculture, Federal University, Oye-Ekiti, Ekiti State, \\ Nigeria \\ ${ }^{2}$ Department of Agricultural Economics, Faculty of Agriculture, Ladoke Akintola University of Technology, Ogbomoso, Nigeria
}

\begin{abstract}
Maize consumption is widespread across the country and among households of different wealth. The challenge to increase the efficiency in food production level in Nigeria appears to be more urgent now than it has ever been in the history of the country and in particular, Kajola Local Government area of Oyo State. This study analyzes the technical efficiency and profitability among maize base farmer in Kajola Local Government of Oyo State. A multi-stage sampling technique was used to select 80 maize based farmers in the five villages using well-structured questionnaire. Descriptive statistics, gross margin and stochastic frontier analysis were employed to analyze the data collected. Result showed that the mean age and household size of the respondents were 46 years and 5 respectively. The profitability analysis showed a profit of $\$ 2711842.6$ was recorded. The stochastic analysis revealed that capital, is the most important factors to increase maize productivity. The study concluded that the productivity of the factors could be improved by expanding the capital base, and adequate and timely education through constant training in the latest farming techniques while alternative capital sources through financial capital (savings, funding, remittances etc.) government grants, be available to farmers in other to boost production.
\end{abstract}

Key words: Maize, Technical efficiency, Profitability, Stochastic Frontier, and Gross margin

\section{INTRODUCTION}

$\mathrm{M}$ ost common characteristic of Nigeria is an agrarian economy with $70 \%$ of its people dependent on agriculture (NBS, 2007). Agriculture is dominated by peasant farmers relying mainly on traditional method and crude implements (Njiforti2008).The Government of Nigeria has been trying to achieve food security at both household and national level through its mechanized approach. It is however surprising that, with all her potentials, agricultural progress can hardly meet its food requirements. Some of the challenges of food Production in Nigeria according to Federal Ministry of Agriculture and Water Recourses (FMAWR) (2008), have been attributed to several factors such as; small land area cultivated by farmer of less than hectare for cropping; suboptimal supply of agricultural inputs such as fertilizer, limited access to credit. Less than $10 \%$ of irrigable land is under irrigation and only $40 \%$ of the arable land is under cultivation
(Kareem et al., 2008). The ability of the farmer to perform his role in agricultural development according to Ogunsumi et al., (2005), has been on the decline in the last three decades. One of the reasons identified as the causes of the declining performance of the sector is inefficient allocation of available farm resources; Land, Labour, seed, and fertilizer, these managerial resources are inefficiently allocated thereby leading to decrease in productivity and reduced agricultural output. Measuring efficiency is important because this is the first step in a process that might lead to substantial resource saving which have economic implication for both policy formulation and firm management (Ajibefun and Abdulkadir, 2004; Usman, 2009).

The possibilities of achieving the desired level of agricultural productivity in the past were indescribable owing to the fact that innovative technologies were introduced to Nigerian agricultural system Olarinde, et al., (2020).The trends in yields have been very disappointing and characterized by very unstable and mostly negative growth. For example, between 1998/2000 and 2001/2003, negative growth rate in yield was observed for maize, sorghum, rice, cassava, yam and rubber. It has also placed a serious stress on the marketing systems (Ojo and Imoudu, 2000). Also Nigeria produced 7.5 million metric tons of maize in 2008 and decline to 7 million metric tons in 2012, Food and Agricultural Organization, FAO (2014). The growth in output in the face of declining yields suggests that the bulk of the production increase is accounted for by expansion in cultivated area. Maize is one of the most important cereal crops in Nigeria where over 150 million people consume an average of 43 kilograms per year (Oyelade and Awanane, 2013). Maize consumption is widespread across the country and among households of different wealth (Cadoni and Angelucci, 2013). The widening gap between food demand and supply in the country which necessitated massive food imports continued to swell Nigeria agricultural import bills despite all remedial measures to assuage the problem.

If Nigeria is to become self-sufficient in maize production, productivity must increase. To achieve this objective, efforts must be taken to examine the productive 
efficiency of maize based farmers in the country. The challenge to increase the efficiency in food production level in Nigeria appears to be more urgent now than it has ever been in the history of the country and in particular, Kajola Local Government area of Oyo State, thereby creating a gap that this study intends to fill. The slow pace of the agricultural sector in Nigeria cannot keep up with the rapid population growth rate, resulting in food shortage, Ataboh, et al., (2014).For sustainable maize production, research is necessary and whether relationship exists between inputs and maize productivity is an empirical question that can be settled only with recent data sets. Kareem et al., (2008), indicate that relationship among input and output is systematically related to the level of development and can best explain the dramatic differences in productivity stem from the utilizations of available resource across heterogeneous farms. Therefore, this study sets to examine thetechnical efficiency and profitability of maize based farmers in Kajola Local Government Area of Oyo State, Nigeria.

\section{LITERATURE REVIEW AND CONCEPTUAL FRAMEWORK}

One of the major challenges faced by farmers in SubSahara Africa (SSA) is the problem of increasing agricultural productivity. Agriculture is pragmatically the main means of livelihood for most families in this region. Careful observation of the agricultural production trend in SSA since 1960s shows that it has suffered from matching up with the increasing population growth. Improving the productivity, profitability, and sustainability of smallholders' farming is therefore the main pathway to get out of poverty. It is widely argued that, achieving agricultural productivity growth will not be possible without developing and disseminating improved agricultural technologies that can increase productivity to smallholder agriculture Olarinde, et al., (2020).

This work is anchored on the theory of production and the related theory of the firm. In agricultural production, the farm firm combines resources such as land, labour, capital and management to produce output. The main goal of the farmfirm may be to maximize profit, minimize cost, and maximize utility (satisfaction) or a combination of all these (Ogundari, et al., 2006). Resource use is a concept used to describe the allocation of farm resources such as land, labour, capital and management in their various forms between competing alternative. In doing this the farm firm aims to derive maximum benefit from these resources. Since resources are scarce and have competing uses, they can limit production of output. For this reason, resources use or allocation is one of the basic functions of an economic system (Nwosu, 2005). According to Nwosu (2005), maximum resource productivity would imply obtaining the maximum possible output from the minimum possible set of inputs; hence optimal productivity of resources implies an efficient utilization of resources in the production process subject to constraints. For the purpose of this study, the following concepts relating to the theory of production were reviewed: Production, Production Function and productivity. Production and productivity are related concepts in economic theory. However, production is not the same as productivity. Production is the same as output. It is physical produce and can be reported in units of volume or weight. Productivity is defined as the output per unit of input where input can be land, labour or capital, and output is agricultural produce (in this case). Kamajou (1991) defined production as the output of goods and services coming from the production (manufacturing) process and productivity as output or production per unit of inputs used. Production has also been defined as the rate at which resources (inputs) are transformed into products, and the production function as the technical relationship between inputs and output in a given period of time (Mijindadi, 1980,Ogundari, et al., 2006). According to Adewusi (2006), production is the ratio of output to inputs used to produce goods and services while productivity is the index which allows assessment of efficiency and effective utilization of resources to obtain a certain output.

Mathematically, the production function is continuous and differentiable, and this property of differentiability enables its use to estimate the 43 rates of return (Ogundari, et al., 2006, Battese and Coelli,1988,Adewusi,2006). The purpose of the production function is to identify and measure how variable inputs are able to explain the variability in outputs. The greater the extent to which variable inputs explains variability in the output, The greater their influence (or explanatory power). For any production function, the correct functional form can be determined by fitting various feasible functional forms to obtain the best fit which is normally selected on the basis of economic, statistical and econometric soundness (Omolola, 1998; Nwosu, 2005). The simplest mathematical form of the production function can be stated as

$$
Q=F\{X\}
$$

Where $\mathrm{Q}=$ output,

$\mathrm{X}=$ inputs and

$\mathrm{F}=$ function of indicating causal relationship between $\mathrm{Q}$ and $\mathrm{X}$.

Heady and Dillion (1972) and Nwosu (2005) explained that various functional forms can be used to describe production relationships, but in practice the most commonly used forms include the linear, quadratic and Cobb Douglass functional forms. According to Adewusi (2006), increase in productivity could be due to technological advances, improvement in managerial advances, and techniques of efficient use of inputs used in the production process. He identified the following ways of productivity increase: (i) increase in output and inputs, with output increasing more proportionately than inputs, (ii) increase in output while inputs remain the same (iii) decrease in both output and inputs with inputs decreasing proportionately more than outputs, and (iv) decrease in inputs 
while output remain the same. FAO (2007) observed that increase in productivity can contribute to economic growth by providing more food, increasing the prospects for growth and competiveness on the agricultural market, income distribution and savings, and labour migration to other sectors.

An increase in a nation's agricultural productivity implies a more efficient distribution of scarce resources. It is believed that farm productivity is functionally dependent on quantifiable parameters which individually and collectively as regress exhibit a causal relationship being best represented by a regression model (Koutsoyiannis, 2001,Kamajou 1991) identified two ways by which productivity increases can come as improvement in technology and improvement in the quality and organization of resources used in production. Ajibefun (2002) and Amasa (2005) have observed that this is important for Nigeria where raising the production per unit of land is the key to effectively addressing the challenges of achieving food security since most cultivable land has already been brought under cultivation, and even in areas where wide expanse of land is still available, physical and technological constraints prevent large scale conversion of potentially cultivable land. Proper use of available resources such as land is thus very essential.

Measurement of Productivity measures are subdivided into partial and total measures. According to Ohajiana (2000), partial productivity measures are the amount of output per unit of a input such as labour, land and capital. Commonly used measures are yield (output per units of land), labour productivity (output per economically active person (EAP) or per agricultural person-hour. Yield is commonly used to assess the success of new production practices or technology. Labour productivity is often used to compare productivity of sectors within or across economies. It is also used as an indicator of rural welfare or living standards. It reflects the ability to acquire income through sale of agricultural goods or agricultural production. According to Fakayode et al., (2009) total factor productivity (TFP) or total productivity is the ratio of the output to the total variable costs of production as shown:

$\mathrm{TFP}=\mathrm{Y} / \mathrm{TVC}$,

Where TFP = total factor productivity,

$\mathrm{Y}=$ total output,

$\mathrm{TVC}=$ total variable costs of production

Alternatively put, TFP $=Y / \sum P_{i} X_{i}$

Where $\mathrm{P}_{\mathrm{i}}=$ unit price of the variable input,

$X_{i}=$ quantity of the variable input.

$\sum=$ summation sign

This methodology ignores the role of total fixed costs as this does not affect both the profit maximization and resource-use efficiency condition. Besides, TFC is fixed and as such a
constant,Fakayodeet al, (2009). Using the cost approach, Fakayodeet al.,(2009) established that TFP can be measured as the inverse of unit variable costs. From cost theory, $\mathrm{AVC}=\mathrm{TVC} / \mathrm{Y}$, where $\mathrm{AVC}=$ average variable cost $(\mathrm{N})$, therefore, TFP $=$ Y/TVC $=1 /$ AVC. As such, TFP is the inverse of AVC. The partial productivity estimates are the marginal products (MP) given as:

$\mathrm{MP}=\partial T F P / \partial X$

Where $\mathrm{X}=$ variable factor

Determinants of Productivity according to FAO (2001) are that productivity is affected by the level of investment. Investment refers to the change in fixed inputs used in the production process. Narrowly defined investment means change in physical capital that has a useful life of one year or longer (land, equipment, machinery, storage facilities, livestock). Agricultural investment should include improvements on land, development of natural resources, and development of human and social capital in addition to physical capital formation. Bernard, (2003) grouped factors that affect agricultural technology as follows: (i) Physical factors such as land area, soils and climate. (ii) Technological factors such as availability of technical know-how input (iii) Human factors such as the way society makes use of the physical and technological factors. One of the most important ways of increasing agricultural productivity is through improved crop husbandry practices such as better weeding, use of improved planting materials, recommended plant configuration, good soil management, appropriate timing of cultural operations, optimal use of labor, and use of external inputs such as fertilizers, machines and pesticides.

According to Fakayode, et al., (2009) other factors include technology, labor employment, education and training of farm operators, agro environmental conditions, security of land ownership rights, and funding which determines the maximal physical quantity of output that can be reached as well as the number and quantity of inputs required. Okuneye (1986) observed that one of the causes of the decline in agricultural productivity is the inefficient allocation of resources in the agricultural production potentials of the economy. He noted that land, labour, capital and water resources are inefficiently allocated thereby leading to decrease in productivity.

\section{METHODOLOGY}

This study was carried out in Kajola Local Government Area of Oyo State. Kajola Local Government is located between latitude $9^{0}$ and $12^{\circ} \mathrm{N}$ and longitude $6^{0}$ and $9^{\circ} \mathrm{E}$ having headquarter in Oke Ogun. It has a total landmass of 68.0sq km and a population of about 100,815(according to 2006 census). Also having an annual rainfall of between $1500 \mathrm{~mm}$ and 2000mm. Kajola LGA is having guinea savanna vegetation. The major crops grown in the study area include cashew, cassava, maize and yam. The main inhabitant of the LGA is the Yoruba people. Kajola Local Government has ten 
council, Namely, Alata, Alapata, Arowomole, Ibapon, Ijeru, Isoko, Lagbabu, Ishapa and Oke-ola. The local Government is made up eight departments which are, Agricultural department, Administrative, Finance, Works, Primary health care, Budget planning, Research and Statistics, Environmental and Natural Resources. Majority of the individuals in the study area are into trading, and a minor are into agriculture, according to Nigeria head counting (NBS,2006)

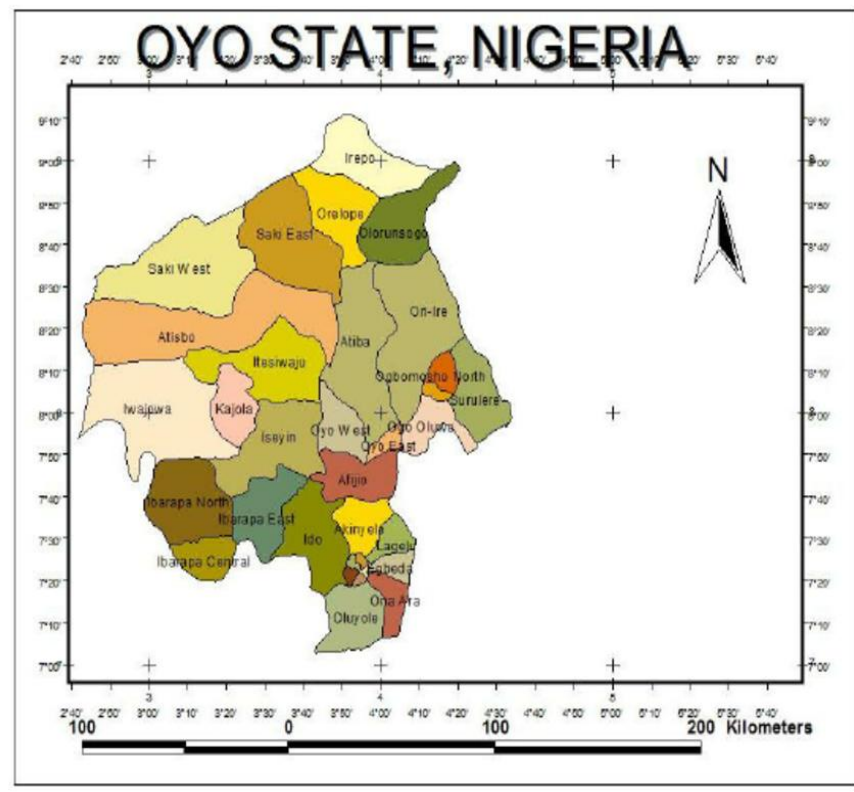

Map Of Oyo State Showing Kajola Local Government, Okeho.

Sampling techniques and sample size

A multi-stage random sampling procedure was used in the study. The first stage was purposive selection of kajola Local Government because of the large number of maize in the area The second stage was the random selection of 5 (five) villages in the local government out of 17(seventeen) villages in the Local Government according to the list from the information unit at the Local Government headquarter in Okeho, in addition to the ones on internet. The third and last stage was the random and representative selection of 16(sixteen) farmer from each of the 5 (five)villages to make a total number of 80(Eighty) respondent maize based farmer were selected. Descriptive statistics, Gross margin analysis, and stochasticfrontier model was used for analyzing the objectives for the study.

\section{Gross margin analysis}

Gross Margin Analysis was used to estimate the profitability of the respondents in the study area. The gross margin analysis tells us the profit a farmer makes on its cost of sales, or cost of goods sold. In other words, it indicates how efficiently the management uses labor and supplies in the production process. Gross Margin analysis is a great way to understand the profitability of farmers. It tells us how effectively management can wring profits from sales.
However, the Gross margin (GM) analysis of maize production in the study area can be expressed as;

$\mathrm{GM}=\mathrm{TR}-\mathrm{TVC}$

$\mathrm{TR}=\mathrm{P} \times \mathrm{Q}$

$\pi=\mathrm{GM}-\mathrm{TFC}$

Where GM = Gross Margin in Naira

$\mathrm{TR}=$ Total Revenue in Naira

$\mathrm{TVC}=$ Total Variable cost in Naira

$\mathrm{P}=$ Price of maize in Naira

$\mathrm{Q}=$ Quantity of maize in $\mathrm{Kg}$

$\pi=$ Profit

The stochastic frontier production function analysis

This study specifies the stochastic frontier production function using the Cobb-Douglass frontier production function. The Cobb-Douglass stochastic frontier model is specified as;

$\ln Y_{i}=\beta_{o}+\beta_{\ln X 1}+\beta_{2 \ln X 2}+\beta_{3 \ln X 3}+\beta_{4 \ln X 4}+\beta_{5 \ln X 5}+V_{i}-U_{i}$

Where; $\ln =$ Natural Logarithm

$\mathrm{Y}_{\mathrm{i}}=$ Output of maize produced $(\mathrm{kg})$

$\mathrm{X}_{1}=$ Farm size (ha)

$\mathrm{X}_{2}=$ Quantity of seed used $(\mathrm{kg})$

$\mathrm{X}_{3}=$ Labour input used (man days)

$\mathrm{X}_{4}=$ Quantity of fertilizer $(\mathrm{kg})$

$\mathrm{X}_{5}=$ Agrochemicals (Liters)

$\mathrm{X}_{6}=$ Cost of seed(Naira)

$\mathrm{V}_{\mathrm{i}}=$ Error term which are random variables

$\mathrm{U}_{\mathrm{i}}=$ Error term which are non-random variables or technical inefficiency effect

$\beta_{o}=$ Intercept

$\beta_{1}-\beta_{5}=$ Regression coefficient

The technical inefficiency model is defined by; $U_{i}=\delta_{o}+\delta_{1} Z_{1}$ $+\delta_{2} Z_{2}+\delta_{3} Z_{3}+\delta_{4} Z_{4}+\delta_{5} Z_{5}+\delta_{6} Z_{6}+\delta_{7} Z_{7}+e_{i}$

Where,

$\mathrm{U}_{\mathrm{i}}=$ Technical inefficiency effect of the ith farm

$\mathrm{Z}_{1}=$ Age (years)

$\mathrm{Z}_{2}=$ Household size (Number of persons)

$\mathrm{Z}_{3}=$ Education level

$\mathrm{Z}_{4}=$ Access to credit (amount borrowed in $\mathrm{N}$ )

$\mathrm{Z}_{5}=$ Extension contact (Number of visit per year) 
$\mathrm{Z}_{6}=$ Gender

$\mathrm{Z}_{7}=$ Farming experience (years)

$\delta_{1}-\delta_{7}=$ Parameters to be estimated

$\mathrm{e}_{\mathrm{i}}=$ Error term

\section{RESULTS AND DISCUSSION}

\section{Socio-economic characteristics}

The age of farmers is one of the major determinants of how active they are. All things being equal, the productivity of a farmer is expected to rise with age as the farmer becomes older and acquires more experience in farming. The result of the age distributions of the respondents is presented in Table 1 . The result shows that $1.25 \%$ of the respondent have their ages to be below 20 years; $31.25 \%$ of the respondents have their ages to be $21-40$ years; $53.75 \%$ have their ages to be $41-60$ years while $12.50 \%$ have their ages to be above $61-80$ years while $1.25 \%$ of the respondent above 80 years. The mean age is 46.13 years. This implies that majority of the respondents are in their active age. This finding is similar to that of Adio and Oladele, (2021) who reported in a study on food security and its determinant on farming household in Surulere Local Government of Oyo State that the mean age of the respondents was 50.91 yearsand Ahmed et al., (2018), in which he observed that youth constitute the majority of the maize farmers. The result of the gender structure of the respondents in Table 1 revealed that the maize farmers were dominated by males, accounting for 80 percent while female accounted for 20 percent. This may be because men are more involved in production at the farm level while women have the tendency to participate more in processing of maize. This agrees with the study of Oni (2016) titled socio-economic determinants and profitability of maize production in Nigeria, he observed that the maize farmers were dominated by males. The result of the marital status of the farmers shows that 71.25 percent were married, 8.75 percent were single, 13.75 percent were widowed and 6.25 were separated. This is a good development because family members of the married will always join and assist in farm work. Their availability reduces labour constraints during the peak of farming season (Tashikalma, et al.,2013), which will eventually lead to increase in maize production in the study area. The result was also in consonance with the findings of Oderhohowo (2008). The implication of the findings is that marriage remains valued in the study area. The higher percentage of married respondents was due to the fact that they derived enough income from maize production to support and sustain their families. According to Zaknayiba et al (2014), the household size is the total number of individuals that live and feed in the household. Due to the labour intensiveness and subsistence nature of Nigerian agriculture, the significance of the size of Nigerian farm household cannot be overemphasized. Because of low level of mechanization, a typical Nigerian farm household relies primarily on human effort provided by the householdmember. Since the highest proportion of labour engaged in farming comes from the family sources, it is expected that, a farming household with higher household size is likely to have more helping hands on the family farm. The mean household size in the study area was 5. This finding is in conformity with that of Oladiran, et al., (2020), where the mean of household size was 6.Since agricultural production activities are labour intensive, large household size can provide farming labour at little or no cost.

Economic activities can be restrained or improved by the overall level of education of individual member of the household. The aspects of educational attainment of respondents which were considered in this study included average years of education within the household, number of household who cannot read and write or barely do so. Education is one of the major factors in the adoption of a new technology. Education is investment in human capital which helps to raise the quality of farmerse farming skills, increase their information and farming efficiency. This helps the farmers to improve their productivity and production efficiency which eventually translates into high standard of living or welfare. This is because education helps unlock the natural, latent or inherent enterprising abilities of farmers. The result in Table 1 further shows that 23.75 percent of the respondents attended primary school; 43.75 percent attended secondary school; 32.50 attended post-secondary school.This result is in agrees with Oladiran, et al., (2020) that indicated that majority of the respondents had formal education which will be of help in business and transaction. This implies that farmers in the area are relatively educated and hence likely to be receptive to new innovations. According to the study, the result of the extension visits (Table 1) shows the how often the respondents are being visited by extension agents. 1.25 percent of the respondents have no contact with extension agents; 98.75 percent have contact with extension agents based on monthly basis. This result shows that most of the respondents have contact with extension agents which imply that there is adequate transfer of information and new technologies between the research institute and maize farmers especially a new variety of maize. Like loan, extension contact is another policy measure that has been shown to be a statistically significant in explaining the adoption decision of innovative practices and technologies (Matthews-Njoku et al., 2009).

Table 1: Socioeconomic Characteristics of the Respondents

\begin{tabular}{|c|c|c|}
\hline Age & Frequency & Percentage \\
\hline$<=20$ & 1 & 1.25 \\
\hline $21-40$ & 25 & 32.50 \\
\hline $41-60$ & 43 & 86.25 \\
\hline $61-80$ & 10 & 98.75 \\
\hline$>80$ & 1 & 1.25 \\
\hline Mean & 46.13 & \\
\hline Sex & & \\
\hline
\end{tabular}




\begin{tabular}{|c|c|c|}
\hline Male & 64 & 80.00 \\
\hline Female & 16 & 20.00 \\
\hline Marital Status & & \\
\hline Married & 57 & 71.25 \\
\hline single & 7 & 80.00 \\
\hline Widowed & 11 & 93.75 \\
\hline Separated & 5 & 100 \\
\hline Household Size & & \\
\hline$<=5$ & 54 & 67.5 \\
\hline $6-8$ & 24 & 30 \\
\hline $9-12$ & 2 & 2.5 \\
\hline Mean & 5 & \\
\hline Education & & 23.75 \\
\hline primary & 19 & 43.75 \\
\hline secondary & 35 & 32.50 \\
\hline Tertiary & 26 & 1.25 \\
\hline Extension Visit & & 98.75 \\
\hline No & 1 & \\
\hline Yes & & \\
\hline
\end{tabular}

Source: Field Survey, 2020

\section{Gross margin Analysis}

Gross margin analysis is an analytical tool used in determining the profitability accruing from the sales from farm produces or an enterprise. Gross margin (GM) for a farm enterprise is the measure of profitability that is a useful aid to enterprise planning. The calculation of Gross Margin can be the starting point for construction of cash flow budgets and assessment of whole profitability. They can also be used to assist in assessing the opportunity to develop new farm enterprises. Gross margin profit is the difference between the annual gross income for the enterprise and the variable costs directly associated with the enterprise.In this study, the gross margin, (GM) is the difference between the Gross Farm Income (GFI) and the Total Variable Cost (TVC) incurred in maize production.

The GM is specified below:

$$
G M=G F I-T V C
$$

The result of the Gross margin showed that the farmer made a profit of 2711842.6

Total Fixed $($ Land $)=\$ 246,365.38$

Total variable cost $=$ Cost of fertilizer + cost of seed

$$
\begin{aligned}
& =\aleph 19,385.46+\aleph 15,975.31 \\
& =\aleph 35,360.77
\end{aligned}
$$

Revenue $=\$ 2993568.75$
Gross Margin $=$ Revenue - TVC

$$
=\mathrm{N} 2993568.75-\mathrm{N} 35360.77
$$

Gross margin $=$ N2958207.98

Profit $=$ GM - TFC

$$
=\mathrm{N} 2958207.98-\mathrm{N} 246,365.38
$$

$=\mathrm{N} 2711842.6$

This result implied that maize production is profitable in the study area.

\section{Estimates of the Determinants of Technical Efficiency}

This sub-section discussed the results of technical efficiency estimates of the maize based farmers. Three functional forms of stochastic production frontier model were fitted (Half-normal distribution, Exponential and Truncated-normal) but only Half-normal distribution provided the best fit based on the explicit detail of the technical efficiency of the maize based farmers as well as the number of significant variables in the model, (Adewumi and Adebayo 2008, Oladimeji and Abdulsalam, 2013).The maximum likelihood estimates (MLE) for the stochastic production function used in explaining the influence of production inputs on the output of maize based farmers and also in determining the effect of farmer specific characteristics on technical inefficiency is presented in Table 2. The parameters were estimated simultaneously using Stata 14.

The value of the sigma squared $(\delta 2)$ is 19.70 and is statistically significant at $1 \%$ level. This also indicates a good fit and correctness of the distributional form assumed for the composite error term in the model. The variance ratio $(\gamma)$ is 0.0019 and also statistically significant at $1 \%$ level, implying that $19 \%$ of the variation in crop output of the respondents is due to differences in their technical efficiencies. This explains the reason why the ordinary least squares (OLS) estimates will not be adequate in explaining inefficiency differentials among the farmers. The coefficients of variables are very important in discussing the result of the analysis of the data. Among the maize based farmers in the study area the efficiency variables that were significant included capital (significant at 5\%), age (significant at 1\%), sex (significant at $1 \%$ ) while the other variables like marital status, household size, education and farming experience were also statistically significant at $1 \%$. By implication, the above findings revealed that the major productive input that has great impact on production of the maize based farmers in the study area wascapital. Capital had the coefficient of 0.047 which is positive in the preferred model (MLE) are by implication the capital is the most important input that had a great impact on the output among the maize based farmers. Therefore for every unit (a naira) increase in capital invested there will be increase in output. 
The estimate parameters of the inefficiency model in the stochastic frontier model of the farmers are also presented in Table 2. The analysis of the inefficiency model shown in the Table (Table 2) showed that signs and significance of the estimated coefficient in the inefficiency model have important policy implication on the technical efficiency (TE) of the maize based farmers. The coefficients of age (3.06), sex (47.88) marital status (5.61), household size (-18.25), farming experience (4.97) and education ($6.98)$ were significant at $1 \%$, respectively andpositive. This implies that these education and household size led to a decrease in technical inefficiency meaning that, increasing them will lead to increase in technical efficiency of maize based farmers in the study area. The more educated the farmers are in addition to greater number of household size( by implication increase in household size increases family labour as members of the family are used on the farm), the more efficient the farmers are all other things being equal. This result agrees with the work of Ataboh et al. (2014) in their study on determinants of Technical Efficiency among Rice Farmers in Kogi State, Nigeria.

\section{The Farmer's-Specific Technical Efficiency}

The individual technical efficiency obtained using the estimated stochastic frontier models shows that the predicted technical efficiency differs substantially among the food crop farmers. The efficiency of male farmer range from 0.3 and 0.9 , while the technical efficiency of female farmers ranges from 0.07512 and 0.99997 . The mean technical efficiency estimated to be 0.84 for the maize based farmers in the study area.The frequency distribution of the technical efficiencies is presented in Table 3 . This is done to give a better indication of the distribution of the technical efficiencies. The frequencies of the occurrence of the predicted technical efficiencies indicate that maize based farmers have 80 percent. The results here imply that given the very wide variation in the level of technical efficiency, there appears to be more than considerable room for effecting greater improvement in the technical efficiencies of the farmers.This result is similar to the work of Ataboh et al., (2014), Oyewole and Ebukiba, (2010) and Usman, (2011).

Table 2. Results of maximum likelihood estimates of stochastic frontier production function of maize production

\begin{tabular}{|c|c|c|c|c|c|c|c|}
\hline & \multicolumn{4}{|c|}{ Normal/Half-normal Model } & \multicolumn{3}{|c|}{ Normal/truncated-normal Model } \\
\hline & Variable & Coeff & Std. Error & p-value & Coeff & Std. Error & p-value \\
\hline & Land & -554.60 & 612.63 & 0.365 & -592.94 & 615.83 & 0.336 \\
\hline & Labour & -0.3823 & 0.3399491 & 0.261 & -0.372145 & 0.3418751 & 0.276 \\
\hline & Capital & 0.1610 & 0.0811148 & $0.047 * *$ & .1563733 & 0.0814786 & $0.055 * *$ \\
\hline & Constant & 25812.3 & 3656.10 & 0.000 & 257995.15 & 31030.13 & 0.406 \\
\hline \multicolumn{8}{|l|}{ Insig2v } \\
\hline & Constant & 19.692 & 0.1580992 & $0.000 * * *$ & & & \\
\hline \multicolumn{8}{|l|}{ Insig $2 \mathrm{u}$} \\
\hline & Age & 3.056 & 0.0053977 & $0.000 * * *$ & & & \\
\hline & Sex & 47.877 & 0.1579675 & $0.000 * * *$ & & & \\
\hline & Marital Status & 5.611 & 0.1143396 & $0.000 * * *$ & & & \\
\hline & Household size & -18.253 & 0.0444091 & $0.000 * * *$ & & & \\
\hline & Experience & 4.970 & 0.0105617 & $0.000 * * *$ & & & \\
\hline & Education & -6.980 & 0.448 & $0.000 * * *$ & & & \\
\hline & Constant & -186.545 & & & & & \\
\hline Sigma_v & & 18883.38 & 1492.72 & & & & \\
\hline$/ \mathrm{mu}$ & & & & & -.0156417 & 63846.1 & \\
\hline /insigma2 & & & & & 19.70 & 0.1581139 & \\
\hline /ilgtgamma & & & & & -24.69 & 754360.9 & \\
\hline Sigma2 & & & & & $3.61 \mathrm{e}+08$ & $5.70 \mathrm{e}+07$ & \\
\hline Gamma & & & & & $1.90 \mathrm{e}-11$ & .0000143 & \\
\hline Sigma_u2 & & & & & .0068615 & 5176.039 & \\
\hline Sigma_v2 & & & & & $3.61 \mathrm{e}+08$ & $5.70 \mathrm{e}+07$ & \\
\hline
\end{tabular}

Source: Computer Output from Frontier Analysis

$* * *$ Significant at $1 \%$ level

** Significant at $5 \%$ level 
Table 3: Distribution of Farmer-Specific Technical Efficiency for maize based farmers

\begin{tabular}{|c|c|c|c|}
\hline S/N & Range & Frequency & Percentage \\
\hline 1 & $0.31-0.40$ & 01 & 1.25 \\
\hline 2 & $0.41-0.50$ & 02 & 2.5 \\
\hline 3 & $0.51-0.60$ & 05 & 7.25 \\
\hline 4 & $0.61-0.70$ & 06 & 12.5 \\
\hline 5 & $0.71-0.80$ & 10 & 70 \\
\hline 6 & $0.81-0.9$ & 56 & 100 \\
\hline & Total & 80 & \\
\hline
\end{tabular}

Source: Computer Output from Frontier Analysis

\section{CONCLUSION}

The study observed that capital, is the most important factors increasing maize productivity. In addition, the technical efficiency of maize based farmers varied due to the presence of technical inefficiency. The variables such as age, sex, marital status, household size, farming experience and education lead to an increase in technical efficiency of farmers. The productivity of the factors could be improved by expanding the capital base, and adequate and timely education through constant training in the latest farming techniques while alternative capital sources through financial capital (savings, remittances etc.) government grants, be available to farmers in other to boost production. The farmers should be encouraged to join cooperative to have access to simple loans (as against loan from Microfinance or Commercial Banks that are out of reach of smallholder farmers), while give attention to supervision and management in other to gain the relevant experience in running a maize farm and increase their technical efficiency.

\section{REFERENCES}

[1] Adewumi, M O and Adebayo, F A (2008). Profitability and Technical Efficiency of Sweet Potato Production in Nigeria Journal of Rural Development, 31(5), pp $105-120$

[2] Adewusi (2006). Resources Use Productivity of Rural Farmers in Kwara State, Nigeria.ASSET Vol.1, No. 1.Adom, K K. and Liu, R. H. (2002).Antioxidant Activity of Grains.Journal of Agricultural Food.Chem. 9.50(21): 6182-7.

[3] Adio and Oladele, (2021): Food Insecurity and its Determinants among Farming Households in Surulere Local Government Area of Oyo State. South Asian Research Journal of Agriculture and Fisheries, 3(2), pp 10-16

[4] Ajibefin, I.A, Abdukadr, A.O. (2004).Impact of Size of Farm Operation in Resource Use Efficiency in Small Scale-Farming Evidence from South Western Nigeria.Journal of Food and environment. 2004; 2(1):359-364.

[5] Ahmed K. D., Burhan O, Amanuel, A., Diriba, I. and Ahmed, A., (2018). Technical Efficiency and Profitability of Potato Production by Smallholder Farmers: The case of DinshoDistrict, Bale Zone of Ethiopia, Journal of Development and AgriculturalEconomics 10(7). Pp225-235

[6] Amaza, P.S. and Maurice,D. C. (2005).Identification of Factors that Influence Technical Efficiency of Rice Based Production System in Nigeria: A Paper presented at workshop on policies and strategies for promoting Rice Production and Food Security in Sub-Sahara Africa, Cotonou, Benin.
[7] Ataboh, O.E., Umeh, J.C. and Tsue, P.T. (2014) Determinants of Technical Efficiency among Rice Farmers in Kogi State, Nigeria, Journal of Agriculture and Sustainability, 6(1). Pp39-49

[8] Bernard, C.H (2003). Economic Analysis of Cassava Based Cropping System in Crude OilProducing Area. A Case Study of River State, Nigeria; Unpublished Ph.D Dissertation.Zaria, Nigeria.

[9] Battese, G.E. and Coelli, T.J. (1988). Prediction of Firm Level Efficiencies with generalized Frontier Production Function and Panel Data. Journal of Econometrics 38: 387-399.

[10] Cadoni, P. and Angelucci, F. (2013).Analysis of Incentives for Maize in Nigeria.Technical Notes Series, FAO, Rome

[11] Coelli, T.J. (1994). A guide to Frontier Version 4.1: A Computer Programme for Stochastic Frontier Production and Cost Function Estimation. Department of Econometrics, University of New England, Armidale, Australia.

[12] Fakayode, S.B,Rahji, M.A.Y, Oni, O.A. andAdeyemi, M.O. (2009). An Assessment of Food Security Situations of Farm Households in Nigeria:A USDA Approach.The Social Sciences 4 (1), 24-29, Medwell Journals

[13] FAO (Food and Agricultural Organization), (2010).FAOSTATA online data base, available at http://faostatfao.org and http://en.wikipedia.org/wiki/rice.Food Agricultural Organization of United Nation. Rome accessed in June 9th 2013

[14] FAO (Food and Agriculture Organization), (2014).Food and Agricultural Organization Report

[15] Food Agricultural Organization (FAO).(2007). Maize in Human Nutrition.Rome (Italy) FAO Corporate Document Repository, Food And Nutrition Series .

[16] FAO (Food and Agriculture Organization), (2001).Food and Agricultural Organization Report

[17] FMAWR (Federal Ministry of Agriculture and Water Resources), (2008).Planning Research and Statistical Data IITA 1994, IITA Annual Report, Ibadan, Nigeria.

[18] Heady, E. O. and Dillion, J. K.(1972).“Agricultural Production Function".Iowa State College Press. Ames, Iowa, USA. 3(1):33-39.

[19] Kamajou, F. (1991). The impact of Agricultural Price Policy on food and export crop production in Cameroon farming systems based analysis availableonhttp://www.uclouvain.be/cps/ucl/doclecru/document s/TF5M3D15.pdf accessed on 23/01/20211.

[20] Kareem, R. O., Dipeolu, A. O., Aromolaran A. B. and William, S. B. (2008). Economic Efficiency in Fish Farming: Hope for Agro-Allied Industries in Nigeria. Chinese Journal of Oceanology and limnology.26 (1): 104-115.

[21] Koutsoyiannis, A. (2001). Theory of econometrics: An Introductory Exposition Of Economic Methods.2nd Edition. Palgrave Macmillan

[22] Mattews-Njoku, E, D. Ohajianya, C. Nwachukwu, E.U. Onweremadu and C.C. Asiabaka, (2009). Determinants of 
Adoption Cover CroppingTechnology: An Application of MultivariateLogistic Analysis in Imo State, Nigeria. Proceedings of the international Conferenceon Global food Crisis: Theme, Global Food Crisis: The Way Forward, Fed. Univ. of Techn.Owerri, Nigeria. 387-392

[23] Mijindadi, N.B. (1980).Production efficiency on farms in Northern Nigeria.Unpublished Ph. D.Discretion. Cornell University, USA. Masterson, T. (2007).Productivity, Technical Efficiency, and Farm Size in Paraguayan Agriculture, The levy Economics Institute of Bard College Working Paper.490.

[24] Muhammad-Lawal A., Omotesho, O.A., and Oyedemi, F.A. (2013). An Assessment of The Economics Of Cassava Processing in Kwara State, Nigeria. Invited paper presented at the 4th International Conference of the African Association of Agricultural Economists, September 22-25, 2013, Hammamet, Tunisia

[25] National Bureau of Statistics (2006).Facts and Figures about Nigeria.National Bureau of Statistics. Abuja, Nigeria.

[26] National Bureau of Statistics (2007).Facts and Figures about Nigeria.National Bureauof Statistics. Abuja, Nigeria.

[27] Ndaeyo, N. U. (2007).Assessing the Contributions of Homestead Farming to Food Security in a Developing Economy: A Case Study of Southeastern Nigeria. Journal of Agriculture and Social Science.3 (1): 11-16.Nigeria. Department of Agricultural Economics and Extension, University of AdekunleAjasin, Akungba-Akoko, Ondo State, Nigeria.Asian Journal of Agricultural Extension, Economics \&Sociology30(4): 1-10, 2019; Article no.AJAEES.46823ISSN: 2320-7027

[28] Njiforti, P. P. (2008). Empirical Examination of Agricultural Sector in Nigeria (1981-2003). Nigerian Journal of Contemporary Public Policy Issues.2 (1): 83-117.

[29] Nwajiuba, C., Margraf, V. and Weikersheim, G. (2012). Does Agriculture have a Future in Inaugural lecture Imo State University Owerri, Nigeria.

[30] Nwosu, C. S. (2005). Comparative Economics of Resource Proceedings of the 39th Annual Conference of Agricultural Society of Nigeria, University of Benin, October 9th - 13th, pp $1-4$.

[31] Ogundari, K.,Ojo, S.O. and Brummer, B.(2006). Productivity Potential and Technical Efficiency of Aquaculture Production in Alleviating Poverty.Empirical Evidence from Nigeria.J. of Fisheries International, 1(1-2):21-26.

[32] Ogunsumi, I. O., Ewuola, S. O. and Daramola, A. G. (2005).Socio-Economic Impact Assessment of Maize Production Technology on Farmers "Welfare in South West, Nigeria.Journal of Central European Agriculture.6 (1): 15-2.

[33] Ohajiana, D.O. (2000). Gender, farm size and relative efficiency in rice production systems in Ebonyi State, Nigeria: A profit function. Unpublished Ph.D Thesis. Federal University of Technology, Owerri.

[34] Ojo, S. O. and Imoudu, P. B. (2000)."Efficiency Measurement of Palm Oil Marketing in Ekiti State of Nigeria” African Journal of Business and Economic Research.1 (2): 7-12.

[35] Okuneye, P. S. (1986). Farmers"e Production Behaviour and Agricultural Labour productivity in Nigeria: Social Change. Journal of the Council for Social Development. 16(4): $12-19$.

[36] Oladiran, J. O., Ogunniyi, L. T. and Fanifosi, G. E. (2020).Factors Influencing Market Participation among Food Crop farmers in Oyo State: A Double Hurdle Approach. South Asian Research Journal of Agriculture and Fisheries. 2(4) pp $85-92$

[37] OladimejiY. U. and Abdulsalam,Z. (2013).Analysis of Technical Efficiency and Its Determinants among Small Scale Rice Farmers in Patigi Local Government Area of Kwara State, Nigeria, Journal of Agriculture and Veterinary Science, 3(3), 34-39

[38] Olarinde, L., Ogunniyi, L., Fanifosi, G.,Adio, M., and Akanbi, E., (2020). Estimating Technical Efficiencies and Productivity
Gaps among Smallholder Farmers in and around FADAMA Farming Communities of South-Western Nigeria.Journal of Xi' an Shiyou University, Natural Science Edition16, (9), pp 81-100

[39] Oyelade, O. A. and Anwanane N. B. (2013).Maize and Cowpea Production in Nigeria. Advances in Agriculture, 3 (11) 1343 1358. Oyelade, O. A. and Anwanane N. B. (2013). Maize and Cowpea Production in Nigeria. Advances in Agriculture, 3 (11) $1343-1358$.

[40] Oyewole, S.O. and Ebukiba, E. S. (2010). Analysis of Technical Efficiency and its Determinants among Small Scale Rice Farmers in Lafia Local Government Area of Nasarawa State, Nigeria.Agriculture and Biology Journal of North America

[41] Tashikalma A. K, Sani, R. M. and Giroh, D. Y.(2014)Comparative Profitability Analysis of selected RainfedTransformation Action Plan. Agricultural Transformation Agenda.Abuja,Nigeria: Federal Ministry of Agriculture and Rural Development.

[42] Usman, S. (2009). The Central Bank of Nigeria: Rural Finance Policies and the Agricultural Credit Guarantee Fund. In After the Reforms: Which Way Forward for Central Banks in Rural finance. AFRACA Rural Finance Series. 1: 56-61.

[43] Usman, A. (2011). Analysis of Technical Efficiency and Its Determinants among Small Scale Rice Farmers in Niger State.Unpublished MSc. Dissertation.Department of Agricultural Economics and Rural Sociology, Ahmadu Bello University, Zaria, Nigeria.

[44] Zaknayiba, D.B., Agwale, A. O., and Bello, D. (2014).Profitability Analysis of Cassava Production in Wamba Local Government Area.Production, Agriculture and Technology Journal,: Department of Agricultural Economics and Rural Sociology AhmaduBello University 